\title{
Development of Acute Myelogenous Leukemia in an Allogeneic Hematopoietic Stem Cell Transplantated Patient with Fanconi Anemia
}

\section{Fankoni Anemisi Olan Bir Allojenik Hematopoietik Kök Hücre Transplantasyonu Yapılmış Hastada Akut Miyeloid Lösemi Gelişimi}

\author{
Alparslan Merdin ${ }^{1}$, Jale Yıldız ${ }^{1}$, Mehmet Sinan Dal ${ }^{1}$, Merih Kızıl Çakar ${ }^{1}$, Ali Hakan Kaya ${ }^{1}$, Emre \\ Tekgündüz ${ }^{1}$, Aykut Onursever ${ }^{2}$, Fevzi Altuntaş ${ }^{1}$ \\ ${ }^{1}$ Dr. Abdurrahman Yurtaslan Ankara Onkoloji Eğitim ve Araştırma Hastanesi, Hematoloji Kliniği ve Kemik İliği \\ Nakil Ünitesi, Ankara, Türkiye \\ ${ }^{2}$ Dr. Abdurrahman Yurtaslan Ankara Onkoloji Eğitim ve Araştırma Hastanesi, Patoloji Bölümü, Ankara, Türkiye
}

Dergiye Ulaşma Tarihi: 26.05.2017 Dergiye Kabul Tarihi: 19.11.2017 Doi: 10.5505/aot.2017.83997

\section{ÖZET}

Fankoni Anemisi (FA) aplastik aneminin kalıtsal bir formudur. Hastaların solid kanserler ve lösemiler geliştirmeye artmış eğilimleri vardır. FA ile ilişkili kemik iliği yetmezliği yüzünden yapılan allojenik hematopoietik kök hücre transplantasyonundan sonra akut miyeloid lösemi (AML) tanısı konulan 40 yaşındaki bir kadını anlatıyoruz. Özellikle AML ile ilişkili anormal kromozomları varsa, FA hastaları lösemi gelişimi açısından yakın takip altında olmalidir.

Anahtar Kelimeler: Fankoni anemisi, akut miyeloid lösemi, allojenik kök hücre transplantasyonu

\begin{abstract}
Fanconi Anemia (FA) is an inherited form of aplastic anemia. Patients have an increased tendency to develop solid cancers and leukemias. We describe a 40-year-old woman who was diagnosed with acute myelogenous leukemia (AML) after allogeneic hematopoietic stem cell transplantation due to FA related bone marrow failure. FA patients should be under close follow-up in terms of leukemia development, especially if they have AML-related abnormal chromosomes.

Keywords: Fanconi anemia, acute myelogenous leukemia, allogeneic stem cell transplantation
\end{abstract}

\section{Introduction}

Fanconi Anemia (FA) is an inherited form of aplastic anemia. FA is a disease associated with bone marrow failure and characterized with increased sensitiveness to chromosomal breakage. There are different genes known in the etiology of FA. As FA patients are unable to repair chromosomal damage induced by genotoxic agents, mitomycin $\mathrm{C}$ or diepoxy butane induced chromosomal breakage tests are used for diagnosis. In most of the cases, FA is an autosomal recessive disorder. However, FA may also be inherited as an X-linked disease if the causing gene is FANCB (Fanconi Anemia Complementation Group B). Patients may also have congenital abnormalities such as short stature, kidney or thumb malformations and abnormal genitalia resulting in infertility. FA patients have an increased tendency to develop malignancies. If the competing risks of aplastic anemia and leukemia could be censored, the estimated cumulative probability of development of a solid tumor in FA patients is reported as $76 \%$ by the age of 45 years (1). Allogeneic hematopoietic stem cell transplantation (AHSCT) is the preferable treatment option of FA patients who presents with severe aplastic anemia or AML (2-3). Here, we report a case with FA who received AHSCT because severe bone marrow failure and later developed AML.

\section{Case Report}

A 40 year old woman presented to the emergency department with fever and fatigue. Eight months ago, she received AHSCT for FA 
induced severe aplastic anemia in Germany. She had one healthy child. Physical examination revealed short stature and paled skin. She had no organomegaly or lymhadenopathy. Her body temperature was $38,5^{\circ}$ C. Laboratory findings at diagnosis revealed hemoglobin 9,3 (12-18) $\mathrm{g} / \mathrm{dl}$, total leukocyte count : $17710 / \mathrm{mm}^{3}$ (4200-11000), neutrophil count: $860 / \mathrm{mm}^{3} \quad(1900-8000)$, platelet count: $6000 / \mathrm{mm}^{3}$ (130000-400000), LDH : 341(125-220) U/l. Echocardiography revealed normal left ventricular function. Hand $\mathrm{X}$-ray revealed normal skeletal findings. Abdominal ultrasonography showed no remarkable abnormality. $90 \%$ myeloblast was seen on the bone marrow imprint smear. Pathological evaluation of bone marrow biopsy showed increased reticulin fibers (Grade 2/3) and infiltration with CD33 weak positive blasts that were negative for myeloperoxidase and CD15, which were compatible with AML (Figure 1-2). Flow cytometry analysis detected two cell populations of $33 \%$ myeloblast and 48 $\%$ monoblast/monocytes in the CD45dim gate. Peripheral blood Real-Time PCR analysis for WT1 was positive. Peripheral blood PCR analysis for $\mathrm{t}(8 ; 21), \mathrm{t}(9 ; 22), \mathrm{t}(15 ; 17)$, FLT-3 ITD and inv16 tests showed negative results.

The patient had undergone AHSCT with cyclophosphamide, fludarabine and ATG conditioning approximately 8 months ago. She developed AML after the procedure. She had a "46, XX, del(11)q23, t( $3 ; 21)$ (q26;q22)", karyotype before transplantation. The patient was advised to receive a second AHSCT. According to her preference she went to her primary transplant center in Germany for further treatment and follow-up.

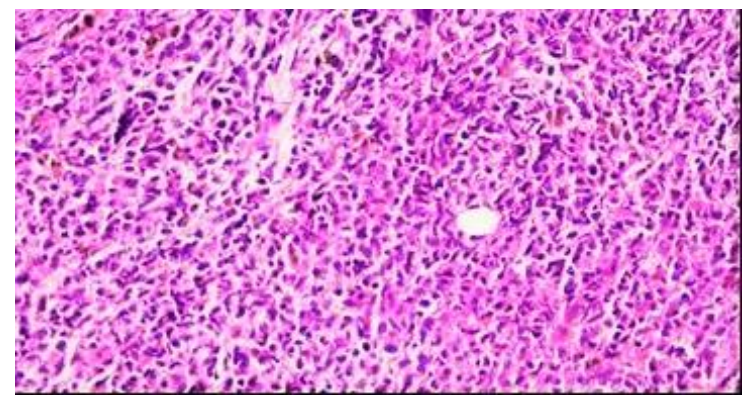

Figure 1. Diffuse blastic infiltration in the fibrotic groud

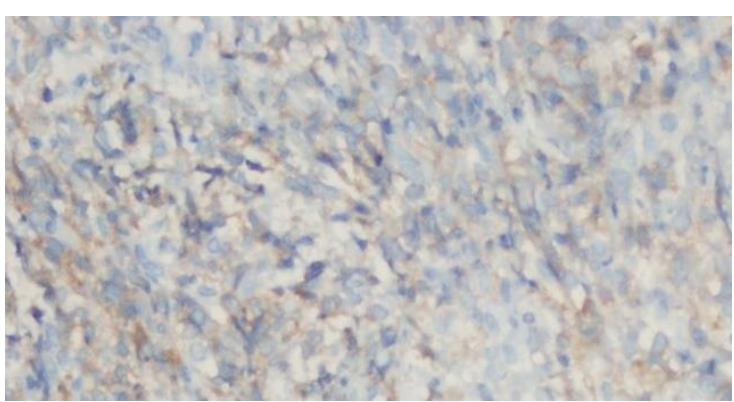

Figure 2. CD33 weak positive blasts

\section{Discussion}

We should always keep in mind the probability of coexistent FA in patients presenting with AML who have one of the malformations associated with FA. FA should also be searched in AML patients who have a history of multiple primary tumors. Rochowski et al. estimated the probability of undiagnosed FA in newly diagnosed AML patients in a treatment trial as around $0.18 \%$ (4). It was also reported in the literature that chromosomes 1,3 , and 7 were more frequently involved in clones in FA associated AML patients than in de novo AML cases $(5,6)$. Besides, abnormalities in chromosomes 8,21,15,17,9,11 and/or 16 could be seen in de novo AML cases. Alter BP et al. reported the median age for cancer in FA patients (including leukemia) as 16 years old in comparison of 68 years old in the general population (1). Our patient had both chromosomal anomalies in chromosomes 3 and 11. On the other hand, she developed AML in the age of 40 and had also chromosome 11 aberration. Therefore the etiology of AML in our patient might be related to multiple chromosomal abnormalities and epigenetic influences.

Curative treatment of the both FA induced aplastic anemia and high risk AML is AHSCT. The management of AML in the course of FA is a difficult issue and evidencebased recommendations are largely lacking (3).

The patient in this report developed AML after treatment of FA induced aplastic anemia with AHSCT. Although she received a reduced-intensity regimen, the impact of conditioning on the development of AML in a patient with background clonal abnormalities can not be overemphasized. Although there is no firm data for the management of such cases, 
the application of a second AHSCT seems to be the only curative option.

In conclusion, FA patients are prone to develop leukemias and solid cancers. Leukemia could develop even after allogeneic hematopoietic stem cell transplantation in FA patients and FA patients should be under close follow-up in terms of leukemia development, especially if they have AML-related abnormal chromosomes.

Conflicts of interest: All authors declare that there is no conflict of interest or financial support in this study.

\section{References}

1. Alter BP. Cancer in Fanconi anemia, 1927-2001. Cancer. 2003 15;97:425-40.

2. Ayas M, Saber W, Davies SM, et al. Allogeneic hematopoietic cell transplantation for fanconi anemia in patients with pretransplantation cytogenetic abnormalities, myelodysplastic syndrome, or acute leukemia. J Clin Oncol. 2013;31:1669-1676.

3. Peffault de Latour R, Soulier J. How I treat MDS and AML in Fanconi anemia. Blood 2016;127:2971-2979.

4. Rochowski A, Rosenberg PS, Alonzo TA, Gerbing RB, Lange BJ, Alter BP. Estimation of the prevalence of Fanconi anemia among patients with de novo acute myelogenous leukemia who have poor recovery from chemotherapy. Leuk Res. 2012;36:29-31.

5. Rochowski A, Olson SB, Alonzo TA, et al. Patients with Fanconi anemia and AML have different cytogenetic clones than de novo cases of AML. Pediatr Blood Cancer. 2012;59:922924

6. Butturini A, Gale RP, Verlander PC, et al. Hematologic abnormalities in Fanconi anemia: An International Fanconi Anemia Registry study. Blood. 1994;84:1650-1655. 